\section{Central European Initiative (CEI)}

In Nov. 1989 Austria, Hungary, Italy and Yugoslavia met on Italy's initiative to form an economic and political co-operation group in the region.

Members. Albania, Austria, Belarus, Bosnia-Herzegovina, Bulgaria, Croatia, Czech Republic, Hungary, Italy, Macedonia, Moldova, Poland, Romania, Serbia and Montenegro, Slovakia, Slovenia, Ukraine.

Address: Executive Secretariat, Via Genova 9, 34132 Trieste, Italy.

Website: http://www.ceinet.org

e-mail: cei-es@cei-es.org

\section{Nordic Council}

Founded in 1952 as a co-operative link between the parliaments and governments of the Nordic states. The co-operation focuses on Intra-Nordic co-operation, co-operation with Europe/EU/ EEA and co-operation with the adjacent areas. The Council consists of 87 elected MPs and the committees meet several times a year, as required. Every year the Nordic Council grants prizes for literature, music, nature and environment.

Members. Denmark (including the Faroe Islands and Greenland), Finland (including Åland), Iceland, Norway, Sweden.

Address: Store Strandstræde 18, DK-1255 Copenhagen K,

Denmark.

Website: http://www.norden.org/

e-mail: nordisk-rad@norden.org

President: Ole Stavad (Denmark).

\section{Nordic Development Fund (NDF)}

Established in 1989, the NDF is a development aid organization of the five Nordic countries, Denmark, Finland, Iceland, Norway and Sweden. NDF capital totals SDR $515 \mathrm{~m}$. and $€ 330 \mathrm{~m}$. Credits are offered to developing countries, with poorer African, Asian and Latin American countries taking priority.

Address: Fabianinkatu 34, PO Box 185, FIN-00171 Helsinki, Finland.

Website: http://www.ndf.fi

e-mail: info.ndf@ndf.fi

President: Jens Lund Sørensen (Denmark).

\section{Nordic Investment Bank (NIB)}

The Nordic Investment Bank, which commenced operations in Aug. 1976, is a multilateral financial institution owned by Denmark, Estonia, Finland, Iceland, Latvia, Lithuania, Norway and Sweden. It finances public and private projects both within and outside the Nordic area. Priority is given to projects furthering economic co-operation between the member countries or improving the environment. Focal points include the neighbouring areas of the member countries.

Address: Fabianinkatu 34, PO Box 249, FI-00171 Helsinki, Finland.
Website: http://www.nib.int

e-mail:info@nib.int

President: Johnny Åkerholm (Finland).

\section{Council of the Baltic Sea States}

Established in 1992 in Copenhagen following a conference of ministers of foreign affairs.

Members. Denmark, Estonia, Finland, Germany, Iceland, Latvia, Lithuania, Norway, Poland, Russia, Sweden and the European Commission.

Aims. To promote co-operation in the Baltic Sea region in the field of trade, investment and economic exchanges, combating organized crime, civil security, culture and education, transport and communication, energy and environment, human rights and assistance to democratic institutions.

The Council meets at ministerial level once a year, chaired by rotating foreign ministers; it is the supreme decision-making body. Between annual sessions the Committee of Senior Officials and three working groups meet at regular intervals. In Oct. 1999 ministers of energy of the CBSS member states agreed to achieve the goal of creating effective, economically and environmentally sound and more integrated energy systems in the Baltic Sea region. Five summits at the level of heads of government of CBSS member states and the President of the European Commission have taken place; in 1996, 1998, 2000, 2002 and 2004. The Baltic Sea Region Energy Cooperation (BASREC) is made up of energy ministers from the region and is chaired by the energy minister from the chair country of the CBSS.

Official language: English.

CBSS Secretariat: Strömsborg, PO Box 2010, S-103 11

Stockholm, Sweden.

Website: http://www.cbss.st

Director of the Secretariat: Dr Gabriele Kötschau (Germany).

\section{European Broadcasting Union (EBU)}

Founded in 1950 by western European radio and television broadcasters the EBU is the world's largest professional association of national broadcasters, with 72 active members in 52 countries of Europe, North Africa and the Middle East, and 50 associate members in 30 countries elsewhere in Africa, the Americas and Asia.

The EBU merged with the OIRT, its counterpart in eastern Europe, in 1993. The EBU's Eurovision Operations Department has a permanent network offering 50 digital channels on five satellites. Two satellite channels also relay radio concerts, operas, sports fixtures and major news events for Euroradio.

Headquarters: Ancienne Route 17, CH-1218 Grand-Saconnex, Geneva, Switzerland.

Websites: http://www.ebu.ch; http://www.eurovision.net e-mail: ebu@ebu.ch

\section{Black Sea Economic Cooperation (BSEC)}

Founded in 1992 to promote economic co-operation in the Black Sea region. Priority areas of interest include: trade and 